https://doi.org/10.19195/0524-4544.333.8

\author{
RENATA KUSIAK-WINTER \\ ORCID: 0000-0002-8202-1360 \\ Uniwersytet Wrocławski \\ renata.kusiak-winter@uwr.edu.pl
}

\title{
Gmina w systemie transformacji energetycznej Niemiec (uwagi na tle nowelizacji ustawy o odnawialnych źródłach energii 2021)
}

\begin{abstract}
Abstrakt: Koncepcja transformacji energetycznej wynikająca z Europejskiego Zielonego Ładu zasadza się nie tylko na transformacji sektora energetycznego, ale zakłada zmianę sposobu funkcjonowania gospodarki i w konsekwencji również społeczeństwa. To z kolei wymaga aktywnego zaangażowania władz publicznych poziomu centralnego oraz władz lokalnych, usytuowanych najbliżej obywatela. W związku z tym, że doświadczenia niemieckie w zakresie promowania odnawialnych źródeł energii uchodzą za wzorcowe nie tylko w Europie, ale i na świecie, celem niniejszego artykułu jest zaprezentowanie najnowszych rozwiązań prawnych przyjętych w Niemczech, umożliwiających uczestnictwo władz lokalnych w systemie wsparcia energii pochodzących ze źródeł odnawialnych.
\end{abstract}

Słowa kluczowe: gmina w Niemczech, transformacja energetyczna, odnawialne źródła energii.

\section{Wprowadzenie}

Mianem transformacji energetycznej określany jest proces przejścia od niezrównoważonego wykorzystania paliw kopalnych i energii jądrowej do zrównoważonych dostaw energii z wykorzystaniem odnawialnych jej źródeł, jej oszczędzania oraz podnoszenia efektywności energetycznej ${ }^{1}$. Początkowo polityka

1 N. Armaroli, V. Balzani, Towards an electricity-powered world, „Energy and Environmental Science" 4, 2011, s. 3193-3222. Na temat pojęcia odnawialnych źródeł energii zob. M. Porzeżyńska, Uwagi na tle pojęcia ,energii ze źródeł odnawialnych” w prawie Unii Europejskiej, „Internetowy Kwartalnik Antymonopolowy i Regulacyjny IKAR" 2019, nr 1, https://sip.legalis.pl/document-full. seam?documentId=mjxw62zogi3damrsgqztmoi (dostęp: 21.04.2021). 
transformacji energetycznej była wdrażana wyłącznie przez wąską grupę proekologicznie myślących państw, takich jak Dania czy Niemcy. Jednak najpóźniej od grudnia 2019 roku, czyli od czasu ogłoszenia komunikatu Komisji Europejskiej pod tytułem Europejski Zielony $\mathrm{Lad}^{2}$, stało się jasne, że to wszystkie państwa członkowskie Unii Europejskiej, bez wyjątku, będą aktywnie realizować politykę transformacji energetycznej. Zgodnie bowiem z założeniami Europejskiego Zielonego Ładu, wizja rozwoju UE wiąże się z koniecznością oddzielenia wzrostu gospodarczego od wykorzystywania zasobów naturalnych, co oznacza potrzebę zmiany systemu funkcjonowania wszystkich gałęzi gospodarki UE, w tym sektora energetycznego. Inaczej mówiąc, to właśnie zmiana systemu energetycznego jest warunkiem sine qua non realizacji ambitnych założeń Europejskiego Zielonego Ładu. Dla uszczegółowienia i skonkretyzowania omawianego tu komunikatu Komisji, który z prawnego punktu widzenia nie zawiera regulacji zobowiązujących ${ }^{3}$, konieczne jest przyjęcie ustawodawczych aktów prawnych UE (art. 289 TFUE) ${ }^{4}$ zawierających postanowienia wiążące dla państw członkowskich. Do najważniejszych z nich należy Rozporządzenie „Europejskie Prawo o klimacie”, które przeszło pomyślnie ostatni etap procedury uzgadniania między instytucjami UE, stając się prawem powszechnie obowiązującym ${ }^{5}$. Rozporządzenie formułuje obowiązek osiągnięcia neutralności klimatycznej przez UE do 2050 roku, przy obniżeniu do 2030 roku emisji netto gazów cieplarnianych o co najmniej 55\% w porównaniu z poziomem z 1990 roku (emisje netto to emisje po odliczeniu pochłaniania).

Realizacja postanowień Europejskiego Zielonego Ładu nakazuje przeprowadzenie transformacji energetycznej w warunkach gospodarki opartej na modelu wzrostu regeneracyjnego (jakościowego), czyli takiego, który zasadza się na oddzieleniu wzrostu gospodarczego od wykorzystywania zasobów naturalnych ${ }^{6}$. To

${ }^{2}$ Komunikat Komisji do Parlamentu Europejskiego, Rady Europejskiej, Rady, Komitetu Ekonomiczno-Społecznego i Komitetu Regionów: Europejski Zielony Ład, COM(2019) 640 final.

${ }^{3} \mathrm{Na}$ temat charakteru prawnego komunikatów Komisji Europejskiej zob. P. Staszczyk, Akty soft law jako reakcja instytucji unijnych na skutki pandemii COVID-19, „Europejski Przegląd Sądowy" 2020, nr 7, s. 41 n. oraz zacytowana tam literatura.

${ }^{4}$ Na mocy art. 289 TFUE (Traktatu o funkcjonowaniu Unii Europejskiej (Dz.Urz. UE C 202 z 7.06.2016, s. 47) akty ustawodawcze to rozporządzenia, dyrektywy oraz decyzje przyjmowane wspólnie przez Parlament Europejski i Radę na wniosek Komisji Europejskiej.

5 Rozporządzenie Parlamentu Europejskiego i Rady w sprawie ustanowienia ram na potrzeby osiągnięcia neutralności klimatycznej i zmiany rozporządzeń (WE) No 401/2009 i (UE) 2018/1999 (Europejskie prawo o klimacie), Bruksela 30 czerwca 2021, PE-CONS 27/1/21.

${ }^{6} \mathrm{Na}$ temat gospodarki regeneracyjnej zob. Wniosek — Decyzja Parlamentu Europejskiego i Rady w sprawie ogólnego unijnego programu działań w zakresie środowiska do 2030 roku, Bruksela 14 października 2020 roku, COM(2020) 652 final. Gospodarka określana mianem regeneracyjnej, daje planecie więcej niż sama bierze, zob. J. Fullerton, Regenerative Capitalism: How Universal Principles and Patterns Will Shape the New Economy, 2015, s. 12 n. Dodajmy, że istotnym elementem wyżej wymienionej koncepcji jest model regeneracyjnego wzrostu (jakościowego wzrostu), wedle którego to zdrowe środowisko i sprawne ekosystemy zapewniają bezpieczną przestrzeń operacyjną dla rozwoju gospodarki. Szerzej na ten temat zob. F. Capra, H. Henderson, 
z kolei wymaga akceptacji społeczeństwa oraz aktywnego zaangażowania nie tylko władz publicznych poziomu centralnego, ale również władz lokalnych, usytuowanych najbliżej obywatela. O ile w doktrynie istnieje dużo opracowań prezentujących rozwiązania stosowane przez władze centralne państw członkowskich, o tyle mniejsza uwaga jest poświęcana kompetencjom władz lokalnych mającym na celu wspieranie i umożliwianie postępów transformacji energetyczno-klimatycznej. W związku z tym, że doświadczenia niemieckie w zakresie promowania odnawialnych źródeł energii uchodzą za wzorcowe nie tylko w Europie, ale i na świecie, celem niniejszego artykułu jest zaprezentowanie najnowszych prawnych rozwiązań obowiązujących w Niemczech, nakierowanych na uczestnictwo władz lokalnych w systemie wsparcia energii pochodzących ze źródeł odnawialnych.

\section{Energiewende jako szczególna droga niemiecka}

Na wstępie warto zaznaczyć, że niemiecka koncepcja Energiewende (transformacji energetycznej) od samego początku stanowi projekt ogólnoniemiecki, czyli zakładający akceptację całego społeczeństwa dla proekologicznych działań władz publicznych. Wysoki stopień poparcia niemieckiego społeczeństwa wynika z wielu czynników, do których bez wątpienia należy silna pozycja organizacji proekologicznych i w konsekwencji stale rosnąca popularność partii Zielonych na scenie politycznej Niemiec ${ }^{7}$. Nie bez znaczenia jest również jednoznaczne stanowisko judykatury, wzmacniające ogólnoniemieckie działania na rzecz Energiewende. Warto tu przywołać najnowszą uchwałę Federalnego Sądu Konstytucyjnego (Bundesverfassungsgericht) z 24 marca 2021 roku$^{8}$, który w odpowiedzi na cztery indywidualne skargi ${ }^{9}$ orzekł, że federalna ustawa o ochronie klimatu

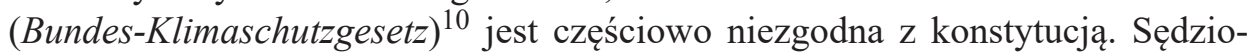
wie, odwołując się do nakazu odpowiedzialności klimatycznej wobec przyszłych

Qualitative Growth. A conceptual framework for finding solutions to our current crisis that are economically sound, ecologically sustainable, and socially just, 2014, https://www.researchgate. net/publication/305003640_Qualitative_Growth_A_Conceptual_Framework_for_Finding_Solutions_to_Our_Current_Crisis_That_Are_Economically_Sound_Ecologically_Sustainable_and_Socially_Just (dostęp: 11.04.2021).

${ }^{7}$ Szerzej na ten temat zob. A. Palzer, H.M. Henning, A comprehensive model for the German electricity and heat sector in a future energy system with a dominant contribution from renewable energy technologies - Part II: Results, „Renewable and Sustainable Energy Reviews” 30, 2014, s. 1019 n.

${ }^{8}$ Bundesverfassungsgericht, Beschluss vom 24. März 2021 (1 BvR 2656/18 u.a.).

${ }^{9}$ Wśród skarżących byli zarówno młodzi aktywiści z organizacji Fridays for Future, jak również mieszkańcy niemieckich wysp Morza Północnego, kwestionujący zbyt mało ambitne cele klimatyczne Niemiec w obawie przed podnoszeniem się poziomu mórz.

${ }^{10}$ Bundes-Klimaschutzgesetz vom 12. Dezember 2019 (BGB1. I S. 2513). 
pokoleń, wynikającego z Porozumienia paryskiego ${ }^{11}$ oraz z art. 20a Ustawy Zasadniczej ${ }^{12}$, zobowiązali ustawodawcę do bardziej szczegółowego uregulowania celów redukcji emisji gazów cieplarnianych na okres po 2030 roku. Zaledwie kilka tygodni po ogłoszeniu ww. orzeczenia rząd przygotował stosowny projekt nowelizacji ustawy, który realizuje obowiązki wynikające z uchwały Bundesverfassungsgericht ${ }^{13}$. Projekt przewiduje, że Niemcy osiągną neutralność klimatyczną już do 2045 roku (a nie do 2050 roku) przy jednoczesnym zobowiązaniu ograniczenia emisji gazów cieplarnianych do 2030 roku o $65 \%$ (a nie o 55\%) oraz do 2040 roku o 88\%. Obok celów głównych projekt ustawy określa cele dla poszczególnych sektorów, takich jak transport, rolnictwo czy budynki, konkretyzujące, ile gazów cieplarnianych mogą one wyemitować w danym roku.

Należy podkreślić, że chociaż najważniejsze ramy prawne stanowi Bundestag, to kluczową rolę w wykonywaniu prawa federalnego pełnią władze krajów związkowych (Bundesländer), gdyż realizacja wszystkich projektów ma miejsce w określonej przestrzeni, co wskazuje również na konieczność zaangażowania władz komunalnych. W granicach swoich kompetencji landy stanowią krajowe ustawy o ochronie klimatu (Klimaschutzgesetze) oraz krajowe ustawy o energii cieplnej (Wärmegesetze), jak również dokumenty strategiczne, określające cele i kierunki rozwoju odnawialnych źródeł energii (OZE) w danym kraju związkowym. Długookresowe plany i odpowiednie programy są przygotowywane w ramach dialogu władz publicznych wszystkich poziomów ze społeczeństwem celem zapewnienia transparentności i szerokiej partycypacji ${ }^{14}$.

Obok ustawy o ochronie klimatu z 2019 roku, podstawowym, a chronologicznie pierwszym, instrumentem transformacji energetycznej w Niemczech była ustawa o rozbudowie energii odnawialnych z 2000 roku (Gesetz für den Ausbau Erneuerbarer Energien) ${ }^{15}$, zwana w skrócie EEG. Stanowi ona system bodźców

11 Porozumienie paryskie do Ramowej konwencji Narodów Zjednoczonych w sprawie zmian klimatu, sporządzonej w Nowym Jorku 9 maja 1992, przyjęte w Paryżu 12 grudnia 2015 (Dz.U. z 2017 r. poz. 36).

12 Zob. Das Grundgesetz für die Bundesrepublik Deutschland vom 23. Mai 1949 (BGBl. 1949 S. 1). Artykuł 20a stanowi: „Państwo, w ramach porządku konstytucyjnego, poprzez ustawodawstwo oraz na mocy ustaw i przepisów prawa, chroni poprzez władzę wykonawczą i sądownictwo naturalne podstawy życia i zwierzęta, również w poczuciu odpowiedzialności wobec przyszłych pokoleń".

13 Zob. Entwurf eines Ersten Gesetzes zur Änderung des Bundes-Klimaschutz-gesetzes, https://www.bmu.de/fileadmin/Daten_BMU/Download_PDF/Glaeserne_Gesetze/19._Lp/ksg_ aendg/Entwurf/ksg_aendg_bf.pdf (dostęp: 12.05.2021).

14 Zob. O. Hohmeyer, S. Bohm, Trends toward $100 \%$ renewable electricity supply in Germany and Europe: a paradigm shift in energy policies, „Wiley Interdisciplinary Reviews. Energy and Environment" 5, 2015, s. 74-97.

15 Pierwszą ustawą EEG była Gesetz für den Vorrang (Erneuerbare-Energien-Gesetz EEG) sowie zur Änderung des Energiewirtschaftsgesetzes und Mineralölsteurgestzes vom 29. März 2000 (BGBl. I S. 305), która przeszła gruntowne (nierzadko systemowe) nowelizacje w 2004, 2009, 2012 (dwukrotnie), 2013, 2014, 2016 i 2017 oraz 2020 roku. 
finansowych dla producentów prądu ze źródeł odnawialnych i od lat uchodzi za kluczowy element polityki rządu niemieckiego w zakresie transformacji klimatycznej, stanowiąc przy tym pierwowzór dla ustawodawstwa w około 60 krajach na całym świecie ${ }^{16}$. Niewątpliwym długofalowym sukcesem ustawy EEG są dane za pierwsze półrocze 2020 roku, wedle których produkcja energii elektrycznej w Niemczech pochodziła w $49 \%$ ze źródeł odnawialnych ${ }^{17}$.

\section{Nowelizacja ustawy \\ o rozbudowie energii odnawialnych z 2021 roku}

17 grudnia 2020 roku Bundestag przyjął nowelę omawianej ustawy, nazwaną EEG 2021 z uwagi na jej wejście w życie z początkiem roku $2021^{18}$. Zakres zmian i doniosłość są spowodowane koniecznością dostosowania do zobowiązań wynikających z Europejskiego Zielonego Ładu. W pierwszym rzędzie nowela prawnie sankcjonuje cel rozbudowy energii elektrycznej ze źródeł odnawialnych na poziomie $65 \%$ w miksie energetycznym do 2030 roku ( 11 ust. 2 pkt 1), co, przypomnijmy, daleko wykracza poza wymagany pułap 55\% w miksie energetycznym UE, zaproponowany w projekcie „Europejskiego prawa o klimacie”. W konsekwencji ustawa określa osiągnięcie celu neutralności klimatycznej jeszcze przed rokiem 2050 i to zarówno w odniesieniu do prądu wytwarzanego na terenie federacji, jak i importowanego zza granicy ( $\$ 1$ ust. 2 pkt 2). Jednak na tym nie koniec, gdyż nowela wprowadza również do osiągnięcia obowiązkowe wielkości: zainstalowana moc farm wiatrowych onshore ma osiągnąć wielkość $71 \mathrm{GW}$ do 2030 roku (osiągnięta dotychczas moc wynosi $54 \mathrm{GW}$ ), farmy offshore zaś powinny osiągnąc moc $20 \mathrm{GW}$ do 2013 roku (moc osiągnięta dotychczas wynosi 7,5 GW). Ponadto nowela tworzy warunki do udostępnienia nowych przestrzeni dla realizacji inwestycji wiatrowych i fotowoltaicznych. Przykładowo, legislator rozszerza katalog przesłanek dla budowy nowych farm fotowoltaicznych na gruncie (§ 36c) oraz łagodzi restrykcje instalacji wiatrowych onshore w zakresie minimalnych wartości siły wiatru na danym terenie. Dla realizacji tak ambitnych celów podkreślono nieodzowność ścisłej współpracy i koordynacji pomiędzy federacją, krajami związkowymi i jednostkami samorządu terytorialnego.

16 S. Wurster, Ch. Hagemann, Expansion of Renewable Energy in Federal Settings: Austria, Belgium, and Germany in Comparison, „Journal of Environment \& Development” 29, 2020, nr 1, s. $147-168$.

17 Agora Energiewende 2020, https://www.agora-energiewende.de/blog/default-5ec368c8fd/ (dostęp: 14.04.2021).

18 Zob. Das Gesetz vom 21. Dezember 2020 zur Änderung des Erneuerbare-Energien-Gesetzes und weiterer energierechtlicher Vorschriften (BGBl. I S. 3138). 
Nowela EEG 2021 jest nakierowana na realizację ambitnych celów określonych w Porozumieniu paryskim i w komunikacie Europejski Zielony Ład. W związku z tym działania nakierowane na osiągnięcie neutralności klimatycznej powinny być zawarte $\mathrm{w}$ odpowiednich postępowaniach administracyjnych o charakterze planistycznym, w zakresie ochrony przyrody i ochrony rzadkich gatunków, zwłaszcza zaś we wszelkich postępowaniach, których przedmiotem jest udzielenie zezwolenia. Dodatkowo ustawodawca zapowiada konieczność skrócenia czasu trwania postępowań. W tym celu władze federacji i krajów związkowych przygotują projekty stosownych rozwiązań ${ }^{19}$.

\section{Gmina a energetyka wiatrowa}

Prawo energetyczne w Niemczech zawarte jest w licznych ustawach, wśród których wymienić należy ustawę o zaopatrzeniu w energię elektryczną i gaz (Energiewirtschaftsgesetz) $^{20}$, ustawę w sprawie kogeneracji (Kraft-Wärme-Kopplungsgesetz) $^{21}$ czy ustawę o oszczędności energii w budynkach (Gebäudeenergiege$s e t z)^{22}$. Chociaż wszystkie wymienione dokumenty stanowią podstawy prawne do podejmowania działań klimatycznych przez jednostki samorządu terytorialnego lub należące do nich przedsiębiorstwa komunalne ${ }^{23}$, to w niniejszych rozważaniach podstawowa uwaga zostanie skierowana na prawne możliwości współuczestnictwa gmin niemieckich w transformacji klimatyczno-energetycznej, wynikające z najnowszej nowelizacji ustawy o energii odnawialnej (EEG 2021).

19 Deutscher Bundestag, Drucksache 19/23482, s. 6.

${ }^{20}$ Energiewirtschafstsgesetz — Gesetz vom 7. Juli 2005 über die Elektriztäts- und Gasversorgung (BGBl. I S. 1970, 3621).

${ }^{21}$ Kraft-Wärme-Kopplungsgesetz — Gesetz vom 21. Dezember 2015 für die Erhaltung, die Modernisierung und den Ausbau der Kraft-Wärme-Kopplung (BGBl. I S. 2498).

22 Gebäudeenergiegesetz - Gesetz vom 8. August 2020 zur Einsparung von Energie und zur Nutzung erneuerbarer Energien zur Wärme- und Kälteerzeugung in Gebäuden (BGBl. I S. 1728 Nr. 37).

23 Przykładowo wspomniana ustawa o zaopatrzeniu w energię elektryczną i gaz reguluje obowiązki tak zwanych podstawowych dostawców energii, którzy zaopatrują odbiorców w gospodarstwach domowych w obszarze sieci zaopatrzenia ogólnego (§ 36). Zobowiązania tyczą się zatem nie tyle gmin, ile zakładów energetycznych, które w praktyce mają różną strukturę własnościową i niekoniecznie stanowią własność komunalną. W zakresie postępów transformacji energetycznej szczególne znaczenie posiada $\S 46$ tejże ustawy, który reguluje przypadki, kiedy gmina zdecyduje się na wygaśnięcie umowy koncesyjnej z prywatnym dostawcą, by zawrzeć umowę z własnym zakładem komunalnym. Wówczas istotną przesłanką przemawiającą za wygaśnięciem umowy może być ekologiczna zgodność eksploatacji sieci, na przykład w sytuacjach rozbudowy sieci w celu przyłączenia elektrowni funkcjonującej w oparciu o odnawialne źródła energii. Inną przesłanką może być zamiar zadośćuczynienia wymaganiom sieciowym dla budowy zdecentralizowanych systemów magazynowania energii lub rozszerzenia elektromobilności, zob. Ch. Theobald, J. Kühling, Energierecht, Energiewirtschaftsgesetz, § 46, Warszawa 2020, Rn. 81. 
Pierwszym i najważniejszym elementem nowelizacji ustawy o energii odnawialnej skierowanym wyłącznie do gmin jest wprowadzenie możliwości udziału finansowego w zyskach z turbin wiatrowych. § 36k ust. 1 EEG zatytułowany został „Udział finansowy gmin” i przyznaje przedsiębiorstwom energetyki wiatrowej onshore możliwość dopuszczenia gminy do bezpośredniego udziału w zyskach do wysokości 0,2 centa za wyprodukowaną kilowatogodzinę. Wprawdzie tak sformułowany przepis nie nakłada na podmioty energetyki wiatrowej prawnego zobowiązania do partycypacji w zyskach przez zainteresowane gminy, jednak z uwagi na znaczący zastój w budownictwie farm wiatrowych onshore ma się on przyczynić do zwiększenia inwestycji pozyskiwania energii z wiatrowych źródeł odnawialnych na lądzie ${ }^{24}$. Należy podkreślić, że jest to opcja ze wszech miar atrakcyjna również dla samych inwestorów, ponieważ w myśl § 36k ust. 3 operator elektrowni wiatrowej otrzymuje zwrot wyżej wymienionej kwoty od operatora sieci. Jak obliczają eksperci, w przypadku nowoczesnych turbin wiatrowych chodzi tu o niebagatelną sumę zasilającą kasę gminną: do wysokości 30 tysięcy euro rocznie na jedną turbinę wiatrową ${ }^{25}$. Tak pozyskane fundusze można przeznaczyć na remont szkół i żłobków lub rozbudowę infrastruktury gminnej.

Według ustawodawcy instrument finansowy zawarty w $\S 36 \mathrm{k}$ stanowi również zachętę dla gmin sąsiednich, gdyż przewidziano możliwość udziału w zyskach gminy, o ile usytuowanie turbin wiatrowych znajduje się w promieniu 2,5 km od ich obszaru. A zatem jeżeli promień przecina obszar kilku gmin, kwotę należy podzielić proporcjonalnie ( $\$ 36 \mathrm{k}$ ust. 1). W związku z tym podstawowym zadaniem gminy jest wyznaczenie odpowiednich obszarów priorytetowych dla turbin wiatrowych oraz negocjowanie korzystnych umów z operatorami ${ }^{26}$.

\section{Gmina a instalacje fotowoltaiczne}

Jak wspomniano wcześniej, przyjęcie noweli EEG 2021 ma na celu stworzenie mechanizmu zachęt nakierowanych na intensyfikację działań w zakresie odnawialnych źródeł energii, by osiągnąć ambitne cele transformacji klimatyczno-energetycznej. W związku z tym przepisy noweli są w większości adresowane do wszystkich podmiotów inwestujących w OZE, wśród których może (i de facto powinna) znaleźć się również gmina. Jednym z najważniejszych filarów noweli EEG 2021 jest wprowadzenie znaczących zmian w odniesieniu do instalacji fotowoltaicznych.

24 Deutscher Bundestag, Drucksache 19/23482, s. 7.

25 TEAG Kommunal, Das neue Erneuerbare-Energien-Gesetz (EEG 2021). Neuer Schwung für die lokale Energiewende, s. 3, https://www.thueringerenergie.de/Content/Documents/TEAG. KOMMUNAL_express_EEG2021.pdf (dostęp: 3.05.2021).

26 Deutscher Bundestag, Drucksache 19/23482, s. 6. 
Zarówno dla gmin, jak i lokalnych przedsiębiorstw komunalnych, fotowoltaika posiada znaczenie gospodarcze ze względu na możliwość własnego zużycia energii słonecznej. Aktualne taryfy obowiązujące w Niemczech wskazują, że konkurencyjne koszty instalacji fotowoltaicznych pozwalają na wytworzenie jednej kilowatogodziny (kWh) energii elektrycznej już za około 5 do 8 centów, podczas gdy koszt energii elektrycznej z sieci publicznej wynosi znacznie więcej ${ }^{27}$. To wystarczający argument przemawiający za umieszczaniem instalacji fotowoltaicznych na dachach nieruchomości komunalnych, takich jak przedszkola, szkoły czy ośrodki pomocy społecznej. W tym zakresie nowela EEG 2021 wprowadza pojęcie małych instalacji fotowoltaicznych o mocy do $30 \mathrm{~kW}$, przeznaczonych na zaspokojenie własnych potrzeb energetycznych (§ 61b). W przypadku takich instalacji ustawa zwalnia prosumentów z konieczności uiszczania obligatoryjnej dotąd tak zwanej opłaty OZE (EEG-Umlage $)^{28}$. Nowe prawo umożliwia zużycie własne energii słonecznej zarówno w nowych, jak i istniejących budynkach, co według danych szacunkowych pozwoli zaoszczędzić do 2,4 centa/ $/ \mathrm{kWh}^{29}$.

Analiza noweli EEG 2021 wskazuje na możliwość wykorzystania przez gminy dużych powierzchni na instalacje fotowoltaiczne, dostępnych przykładowo na gminnych gruntach niezabudowanych lub na dachach komunalnych hal sportowych. W tym zakresie nowela wprowadza różnicowanie procedury przetargowej w zależności od tego, czy jest to instalacja fotowoltaiczna zlokalizowana na otwartej przestrzeni (niem. Solaranlagen des ersten Segments) czy instalacja dachowa (niem. Solaranlagen des zweiten Segments). Jeśli chodzi o fotowoltaiczne instalacje dachowe o mocy zainstalowanej od 300 do $750 \mathrm{~kW}$, to ich posiadacze mają możliwość wyboru: albo uczestniczenia w obligatoryjnych dotychczas przetargach, albo korzystania ze stałego wynagrodzenia (taryfy gwarantowanej), przy spełnieniu warunku samodzielnego zużywania części energii elektrycznej w odniesieniu do co najmniej 50\% wytworzonej energii elektrycznej ( $\$ 22$ ust. 3 oraz $\S 48$ ust. 5 EEG 2021). Natomiast co się tyczy instalacji naziemnych (wolnostojących), to nowela dokonuje podwojenia mocy dostępnej w przetargach, $\mathrm{z}$ dotychczasowych 10 do 20 megawatów mocy ( $\$ 37$ ust. 1). W związku z tym należy stwierdzić, że gmina, nawet jeśli nie jest właścicielem stosownych nieruchomości niezabudowanych (na przykład usytuowanych wzdłuż autostrad lub linii kolejowych ${ }^{30}$ ), dzięki inwestycjom prywatnych operatorów instalacji fotowoltaicznych uzyska odpowiedni dochód z podatku od działalności gospodarczej. Warunkiem

27 TEAG Kommunal, op. cit., s. 5.

28 Deutscher Bundestag, Drucksache 19/23482, s. 3.

29 TEAG Kommunal, op. cit., s. 5.

${ }^{30}$ Należy tu wskazać, że zgodnie z $§ 37$ ust. 1 pkt 2 oraz $\S 48$ ust. 1 pkt 3 szerokość instalacji fotowoltaicznych na otwartej przestrzeni na poboczach autostrad i linii kolejowych wynosi obecnie 200 metrów zamiast dotychczasowych 110 metrów. 
jest przyjęcie odpowiednich aktów zagospodarowania przestrzennego w ramach władztwa planistycznego gminy (Planungshocheit der Gemeinde) ${ }^{31}$.

\section{„Energia elektryczna najemcy” w budynkach komunalnych}

Z uwagi na wysoki odsetek mieszkań komunalnych będących w posiadaniu gmin niemieckich ${ }^{32}$ warto na koniec omówić mechanizm wsparcia przewidziany w noweli EEG 2021 w ramach instytucji tak zwanej ,energii elektrycznej najemcy" (Mieterstrom). Jest to kolejny mechanizm nakierowany na wzrost akceptacji społecznej poprzez wzmocnienie praw prosumentów będących najemcami w budynkach czynszowych. Dodajmy, że mechanizm wsparcia najemców w takich budynkach w zakresie energii ze źródeł odnawialnych nie jest „wytworem” omawianej tu noweli EEG, lecz wcześniejszej nowelizacji pochodzącej z 2017 roku $^{33}$. Nowela EEG 2021 podtrzymuje stosowny system dopłat (do $500 \mathrm{kWp}$ po 2,37 centa/kWh), przy czym dopłaty nie przynoszą bezpośrednich korzyści najemcom, ale dają operatorowi instalacji fotowoltaicznej umiejscowionej na dachu budynku czynszowego większą swobodę w obliczeniach i planowaniu projektu, aby móc sprzedawać energię elektryczną najemcom po obniżonych kosztach. Prawnie uregulowano, że energia elektryczna najemcy nie może przekraczać $90 \%$ standardowej taryfy lokalnego dostawcy energii. § 21 ust. 3 noweli EEG 2021 przewiduje tak zwane uproszczone rozwiązania dzielnicowe (Quartiersansatz), które polegają na tym, że fotowoltaiczna instalacja dachowa nie musi znajdować się w budyn$\mathrm{ku}, \mathrm{w}$ którym najemcy są zaopatrywani w energię elektryczną w systemie prosumenckim. Wystarczy, że instalacja będzie zlokalizowana na tym samym osiedlu (Quartier), na którym znajduje się zasilany budynek. Taka regulacja znacznie poszerza zakres podmiotowy najemców uprawnionych do korzystania $\mathrm{z}$ energii elektrycznej ze źródeł odnawialnych. Na koniec warto wskazać, że model Mieterstrom różni się od dyskutowanego aktualnie w Polsce „prosumenta zbiorowego” tym, że w Niemczech instalacja jest realizowana przez wynajmującego budynek mieszkalny z zamiarem udostępnienia energii elektrycznej najemcom.

31 S. Tomerius, Kommunale Verantwortlichkeiten und Ansatzpunkteim Rahmen der Energiewende Analyse des nationalen kommunalrechtlichen Rechtsrahmens, Berlin 2017, s. 19.

$32 \mathrm{Na}$ ten temat zob. Bundesinstitut für Bau-, Stadt- und Raumforschung, Kommunale Wohnungsbestände in Deutschland, Berlin 2018, https://www.bbsr.bund.de/BBSR/DE/veroeffentlichungen/sonderveroeffentlichungen/2018/kommunale-wohnungsbestaende-dl.pdf?_blob=publicationFile\&v=1 (dostęp: 22.04.2021).

33 Gesetz zur Förderung von Mieterstrom und zur Änderung weiterer Vorschriften des Erneuerbare-Energien-Gesetzes vom 17.07.2017, BGB1. 2017 Teil I Nr 49, s. 2532. 


\section{Wnioski}

Przeprowadzone przeze mnie badania wykazały znaczącą rolę gminy jako podstawowej jednostki samorządu terytorialnego w realizacji celów państwowych, europejskich oraz ogólnoświatowych w zakresie transformacji klimatyczno-energetycznej. To z kolei jest potwierdzeniem podstawowej tezy sformułowanej sto lat temu przez Tadeusza Bigę. Ten wybitny polski administratywista uważał, że przedmiot samorządowej administracji nie różni się od przedmiotu administracji rządowej ${ }^{34}$, co z całą mocą potwierdza, że ochrona klimatu jest typowym zadaniem publicznym, które powinny realizować podmioty administracji publicznej umiejscowione na różnych poziomach. Natomiast przyznanie gminie jako związkowi publiczno-prawnemu ${ }^{35}$ atrybutu samodzielności zakłada, że to samo zadanie wykonywane przez różne podmioty administracji na poziomie lokalnym, regionalnym, państwowym, unijnym czy światowym, będą wykonywane z uwzględnieniem interesów i zagadnień aktualnych dla tych odrębnych podmiotów administracji usytuowanych na różnych poziomach.

Najnowsza nowela EEG 2021 stanowi wzorcowy przykład prawnego usankcjonowania celów dochodzenia do neutralności klimatycznej z uwzględnieniem cezury 2030 roku oraz 2050 roku. Wydaje się, że legislator polski również powinien zawrzeć w ustawie zobowiązanie Polski do podejmowania działań na rzecz neutralności klimatycznej, chociaż — przypomnijmy — ani Europejski Zielony Ład, ani przygotowywane rozporządzenie Prawo o klimacie nie formułują ambitnych celów w odniesieniu do poszczególnych państw członkowskich, lecz w odniesieniu do Unii Europejskiej jako całości. Formułując wnioski de lege ferenda dla polskiego ustawodawcy, warto podnieść znaczenie podejścia systemowego w działaniach legislacyjnych na rzecz neutralności klimatycznej. Chodzi zatem o wyznaczanie ambitnych celów klimatycznych zobowiązujących władze rządowe i samorządowe do podjęcia konkretnych działań, ale również rozbudowania sytemu zachęt finansowych zarówno dla jednostek samorządu terytorialnego (zwłaszcza z uwagi na władztwo planistyczne gminy), jak i dla prosumentów, by ambitne cele ustanowione na poziomie UE były urzeczywistnione również w Polsce.

34 Jak twierdzi T. Bigo: ,przedmiot samorządowej administracji nie różni się od przedmiotu administracji rządowej; z tego punktu widzenia nie można przeciwstawić administracji samorządowej — administracji państwowej, bo samorząd jest tylko odmienną formą organizacyjną administracji państwowej" - idem, Zwiąki publiczno-prawne w świetle ustawodawstwa polskiego, Warszawa 1927, s. 140.

35 Ibidem, s. 154. 


\section{Bibliografia}

Armaroli N., Balzani V., Towards an electricity-powered world, „Energy and Environmental Science" 4, 2011.

Bigo T., Zwiazki publiczno-prawne w świetle ustawodawstwa polskiego, Warszawa 1927.

Capra F., Henderson H., Qualitative Growth. A conceptual framework for finding solutions to our current crisis that are economically sound, ecologically sustainable, and socially just, [w:] From Capitalistic to Humanistic Business, red. M. Pirson, J.R. Mulryne, London 2014.

Fullerton J., Regenerative Capitalism: How Universal Principles and Patterns Will Shape the New Economy, 2015, https://capitalinstitute.org/wp-content/uploads/2015/04/2015ExecSummary4-14-15.pdf.

Hohmeyer O., Bohm S., Trends toward 100\% renewable electricity supply in Germany and Europe: a paradigm shift in energy policies, „Wiley Interdisciplinary Reviews” Energy and Environment" 5, 2015.

Palzer A., Henning H.M., A comprehensive model for the German electricity and heat sector in a future energy system with a dominant contribution from renewable energy technologies - Part II: Results, „Renewable and Sustainable Energy Reviews” 30, 2014.

Porzeżyńska M., Uwagi na tle pojęcia ,energii ze źródeł odnawialnych” w prawie unii europejskiej, „Internetowy Kwartalnik Antymonopolowy i Regulacyjny IKAR” 2019, nr 1.

Staszczyk P., Akty soft law jako reakcja instytucji unijnych na skutki pandemii COVID-19, „Europejski Przegląd Sądowy” 2020, nr 7.

Theobald Ch., Kühling J., Energierecht, Energiewirtschaftsgesetz, § 46, Warszawa 2020.

Tomerius S., Kommunale Verantwortlichkeiten und Ansatzpunkteim Rahmen der Energiewende Analyse des nationalen kommunalrechtlichen Rechtsrahmens, Berlin 2017.

Wurster S., Hagemann Ch., Expansion of Renewable Energy in Federal Settings: Austria, Belgium, and Germany in Comparison, „Journal of Environment \& Development” 29, $2020, \mathrm{nr} 1$.

\section{Local Government and the Transformation of the Energy System in Germany (Remarks on the Renewable Energy Sources Act, Version 2021)}

Summary

The concept of energy transformation resulting from the European Green Deal is based not only on the transformation of the energy sector, but also implies a change in the way the economy and, consequently, the society functions. This, in turn, requires the active involvement of public authorities of the central level as well as local authorities, closest to the citizen. Therefore, the aim of this article is to present the latest legal regulations in Germany aimed at the involvement of local self-government in the support system for energy from renewable sources.

Keywords: local government in Germany, transformation of the energy system, renewable energy sources. 